\title{
Management Accounting in Pricing Decisions for Real Estate of Real Estate Enterprises in Vietnam
}

\author{
Pham Thanh Hương ${ }^{1}$ \\ ${ }^{1}$ Department of Accounting-Auditing, Thuong mai University, Hanoi, Vietnam \\ Correspondence: Pham Thanh Hương, Department of Accounting-Auditing, Thuongmai University, 79 Ho Tung Mau \\ - Cau Giay District, Hanoi, Vietnam.
}

Received: July 20, 2018

Accepted: August 31, 2018

Online Published: September 7, 2018

doi:10.5430/afr.v7n4p35

URL: https://doi.org/10.5430/afr.v7n4p35

\begin{abstract}
In Real Estate Enterprises (REEs), managers always have to make decisions while running their business in various forms. Among the manager's decisions on real estate business, the pricing decision for real estate is one of the difficult decisions for managers in the REEs. Pricing decisions for real estate are often strategic decisions, which play an important role for the existence and development of REEs. Thus, enterprise managers often consider this to be the most important task for its historical mission and decisive factor of other tasks. This paper focuses on analyzing and evaluating the actual situation of Vietnam's REEs in making pricing decisions for real estate, then proposing some recommendations for improving the information system and pricing decisions for real estate making process for creating the highest economic efficiency for the REEs in the current market conditions.
\end{abstract}

Keywords: real estate enterprises, pricing decisions for real estate, real estate

\section{Introduction}

In the context of Vietnam's economy is transforming into market economy as well as the economic integration around the world, our domestic real estate market have made positive changes, greatly contributing to acceleration of our country's socio-economic development at a relatively high pace. Real estate business activities is a business with many characteristics, this business is always influenced by many factors of economic, political, social development and stability of the country, development of science and technology, fluctuation of foreign exchange market, gold, interest rates ... these factors can directly or indirectly affect the results of real estate business. In addition, real estate business activities require a large amount of capital and long-term investment period, these activities are considered to carry many potential risks; this requires that business enterprises in this industry control their operations through the use of multiple management tools. Management accounting is considered one of the most effective management tools to provide useful information for the control and decision making of corporate executives. Among the manager's decisions on real estate business, the pricing decision for real estate is one of the difficult decisions for managers in the REEs. Pricing decisions for real estate are often strategic decisions, which play an important role for the existence and development of REEs.

The pricing decisions for real estate in REEs are influenced by various factors such as the enterprise's internal and external factors, positive factors, negative factors, qualitative factors, and quantitative factors. These factors can be divided into two basic groups, the internal factors including the objectives of the enterprise, the marketing policies of the enterprise, and the product cost; and the external factors including market demands, competitiveness of the same products on the market, macroeconomic policies of the Government, and the overall factors in the business environment. For decision making, the managers shall base on the collected and processed data to retrieve information on the financial reporting system and the management reporting system such as the directions reporting system, results reporting system, fluctuations reporting system and causes of fluctuations then analyze and evaluate this information in the most effective way for making the management decisions of the enterprise. In REEs, management decisions are often divided into two categories namely short-term decisions and long-term decisions. In particular, the investment in and construction of real estate for sale are considered as a production cycle of the REEs starting from the time of capital investment to the time of profit gain. If the above characteristics are taken into account, the pricing decisions of real estate can be considered as short-term decisions. However, if the characteristics of investment and construction of real estate for sale are taken into account requiring huge investment capital and long investment duration which are strategically significant and vital to the existence and development of enterprises, then these decisions are considered 
as long-term decisions. A pricing decision for real estate is the enterprise's determination of the selling price for a specific real estate entity at a predetermined time based on the technical criteria, nature, location, size, and status of the real estate. And that must follow the market mechanism at the time of making pricing decisions to meet the business objectives of the enterprise.

In fact, the pricing decisions for real estate in REEs in Vietnam has still has a lot of inadequacies. According to the survey, most of REEs responded that their pricing decisions for real estate of enterprises have not been really suitable with market conditions, most of the prices are different from those of successful transactions prices of secondary investor in the real estate market. One of the main reasons leading to above situation is due to the information system and the real estate pricing decision-making process have not met management requirements of corporate executives, not a reliable basis for real estate investors to offer appropriate pricing decisions. From the above mentioned issues, this paper shall take into consideration the actual situation of pricing decisions for real estate in Vietnam's REEs then propose some solutions for improving the information system and the real estate pricing decision-making process for creating the highest economic efficiency for the REEs in the current market conditions.

\section{Research Method}

The research method used was the qualitative one with specific studies such as systematic, interpretive, inductive, comparative studies and actual investigation to analyze, evaluate, and draw reasonable conclusions. The research method was specifically implemented as follows:

Data collection method: Primary data collection through survey forms and questionnaires.

(1) Survey method: The survey method was used to collect real information about the actual situation of pricing decisions for real estate of Vietnam's REEs. The survey was conducted by delivering survey forms to managers and accountants of REEs in Hanoi. The survey sample was selected based on case studies of 80 REEs in Hanoi. The reason for selecting case studies in Hanoi was that the characteristics of the real estate business were similar in terms of business activities among regions, the objects of real estate business were not limited by spaces among regions across the country. Based on the research's targets and respondents, the questions on the survey forms were prepared by the author. Before delivering the survey forms, the author has consulted with some chief accountants of REEs for the purpose of identifying questions on the survey forms to suit the respondents. Moreover, the author has also consulted with some experts for comments on the survey form to improve it. Although, the survey sample was selected based on the convenient and cooperation of REEs, but due to real estate business is one of the most sensitive activities in the real estate market in Viet Nam, some REEs refused to respond. As a result, 69 respondents answered the survey forms.

(2) Interviewing method: There were intervals between interviews for the author to have time for reviewing the interview questions for the next interviews. The places for implementing interviews were determined by interviewees, but the author often asked for permission to interview at the interviewee's working places so that they could discuss all issues more openly and there were chances to access the enterprise's data source. The interviewees were divided into two groups namely managers of all levels, internal controls and accountants. Interview questions were often sent in advance for the interviewees to understand the purpose and content of the interviews so that the information obtained would be useful and on focus.

Data processing and analysis: To summarize the survey forms, the collected results were analyzed to make conclusions about the problems. The author used Excel to analyze the results. The results of the survey method are the evaluation data on actual situation of pricing decisions for real estate of REEs in Hanoi, the limitations and shortcomings in pricing decisions for real estate.

\section{Actual Situation of Pricing Decisions for Real Estate of Real Estate Enterprises}

In Vietnam's REEs, according to the results of the survey on the actual situation of pricing decisions, the author divides the pricing decisions for real estate can be made at three points of time namely: the time of real estate project evaluation and construction; the time when enterprises are allowed to raise investment capital from customers and the time when real estate project has been completed.

(1) The time of real estate project evaluation and construction: According to the survey, $53.6 \%$ of REEs conducted real estate pricing at this stage on their own. Enterprises apply the cost norms system published by the competent agencies to make construction cost estimates, calculate the cost price to use as basis for pricing. At this point of time, enterprises do not really pay attention to the real estate pricing. The pricing activity at this time mostly serves the purpose of developing the real estate business plan. However, also according to the survey results, as high as $46.4 \%$ of REEs hired independent real estate appraisal firms to conduct real estate pricing for them. Enterprise managers have based on this appraisal result for the purpose of developing the real estate business plan for their own enterprise. 
(2) The time when enterprises are allowed to raise investment capital from customers: According to the survey, $13.1 \%$ of REEs hired independent appraisal firms to make pricing decisions, while the remainder made pricing decisions for real estate on their own based on the price decided at the time of making cost estimates. These enterprises (including those hiring independent appraisal firms to make pricing decisions at the time of project evaluation and construction) used comparative method and cost method to make pricing decisions again for the real estate. According to the survey, REEs who made pricing decisions for real estate on their own used the established cost estimation system for real estate investment and construction budget and some management accounting reports for analysis and evaluation of information, then gave it to functional departments to make pricing decisions for real estate. The real estate selling price was determined by the formula:

\section{Selling price $=\underset{\text { cost }}{\text { Total estimated }}+\underset{\text { profit }}{\text { Estimated }}+$ Value Added Tax}

In fact, surveys showed that the apartment prices were calculated by REEs based on cost prices:

The pretax VAT selling price by square meter of the usable floor area $=$ The pretax cost price by square meter of the usable floor area + Maintenance costs + predetermined taxable income.

The pretax cost price by square meter of the usable floor area = Total construction cost/Total usable floor area.

The post-tax selling price by square meter of the usable floor area = The pretax selling price by square meter of the usable floor area + Value added tax.

The total estimated cost includes all legal expenses for investment in the construction of works and putting into exploitation and use.

Maintenance costs: For the size of the house sold, the cost of maintenance work is $1 \%$ of the price of the business.

Profit of the project: According to regulations in Viet Nam, social housing profitable norms prescribed maximum of $10 \%$, however for commercial housing no specific provisions for this indicator which is set by the owner depending on the profit target of each business. However, through the actual research, the profit rate applied by REEs is about $10 \%$ to $35 \%$.

For example, the pricing decisions for real estate of Hoa Phat Group were made as follows: For the project at No. 275 Giai Phong street, to determine the selling prices of the apartments at the time when the enterprise was allowed to raise capital from customers, managers based on the cost estimate system to decide the selling prices, then they allocated the total investment costs by square meter of the built floor area. Based on this unit price of square meter of the built floor area, the management accounting department and the department in charge of pricing decisions for real estate determined the selling prices of the apartments after adding $(+)$ the maintenance unit price and the estimated interest rate or expected interest rate of the enterprise. The Group used the comparative method to make a comparison table of their selling prices and other apartment building projects with similar basic features in terms of purposes for use, legal characteristics, economic and technical characteristics, characteristics of location and points of sale. Hoa Phat Group also studied the market trends and conditions at the time of launching project's marketing plan. As a result, the average selling price of the apartment was $33,500,000 \mathrm{VND} / \mathrm{m}^{2}$ (with details for each apartment). It can be said that, at the time of the apartment's pricing decision when the project was allowed to raise capital from customers, there were a lot of expert's opinions stating that price the project at No. 257 Giai Phong street was quite high compared with the real estate market price which was going down. However, thanks to the good location and prestige of the enterprise, when the marketing plan was launched, more than $90 \%$ of the project has been sold. And $100 \%$ of the project has been sold when the project was completed and handed over. However, the surveys also showed that though the price decided by the enterprise was relatively high, in fact, the actual market prices of apartments of the project at No. 257 Giai Phong street ranged from $34,000,000 \mathrm{VND} / \mathrm{m}^{2}$ to $40,000,000 \mathrm{VND} / \mathrm{m}^{2}$.

(3) The pricing decision at the time when real estate project has been completed.

When the project has been completed, $100 \%$ of the surveyed REEs responded that they have made pricing decisions again for customers. However, because the real estate projects are allowed to raise capital right from the beginning of the project, or in other words, the enterprises are allowed to trade right from the beginning of the investment and construction process, REEs shall normally sell most of their real estate products at the selling price at the time they are allowed to raise capital. As a result, surveys showed that most enterprises often keep the original price and if they adjust prices to suit the market conditions they would usually do in the way that the conditions for sales promotion are accompanied. 


\section{Evaluating the Actual Situation of Pricing Decisions of Real Estate Enterprises}

At present, there are no or less effective procedures for making real estate pricing decisions as well as information systems and databases used for making real estate pricing decisions in most of REEs. According to the surveys, $81.2 \%$ of REEs responded that their pricing decisions for real estate of enterprises have not been really suitable with market conditions, most of the prices are different from those of successful transactions prices of secondary investor in the real estate market.

Table 1. Statistics on the selling prices for real estate of some projects in Hanoi

\begin{tabular}{|c|c|c|c|c|}
\hline No. & Project name & $\begin{array}{l}\text { Average price } \\
\text { decided by enterprise } \\
\text { when the project is } \\
\text { allowed to raise } \\
\text { capital } \\
\left(\mathrm{Mil} \mathrm{VND} / \mathrm{m}^{2}\right)\end{array}$ & $\begin{array}{l}\text { The rate of } \\
\text { apartments sold } \\
\text { when the project } \\
\text { is allowed to raise } \\
\text { capital }(\%)\end{array}$ & $\begin{array}{l}\text { Average transactions } \\
\text { prices of secondary } \\
\text { investor in the real } \\
\text { estate market } \\
\left(\mathrm{Mil} \mathrm{VND} / \mathrm{m}^{2}\right)\end{array}$ \\
\hline 1 & $\begin{array}{l}\text { Rainbow Apartment Building in Van } \\
\text { Quan ward }\end{array}$ & 26 & 92 & 28 \\
\hline 2 & $\begin{array}{l}\text { Euroland Apartment Building in Mo Lao } \\
\text { ward, Ha Dong district }\end{array}$ & 24 & 94 & 27 \\
\hline 3 & $\begin{array}{l}\text { Apartment Building at Hoang Van Thai } \\
\text { street }\end{array}$ & 17.5 & 94 & 25 \\
\hline 4 & $\begin{array}{l}\text { M3-M4 Apartment Building at Nguyen } \\
\text { Chi Thanh street }\end{array}$ & 32.5 & 95 & 40 \\
\hline 5 & Geleximco Apartment Building & 16.6 & 88 & 14 \\
\hline 6 & Vincom Ba Trieu Apartment Building & 72.5 & 66 & 85 \\
\hline 7 & The Manor Apartment Building & 35.5 & 45 & 45 \\
\hline 8 & Keangnam Apartment Building & 41.5 & 86 & 45 \\
\hline 9 & 17CT - Vinaconex Apartment Building & 29.5 & 78 & 27 \\
\hline 10 & Vimeco Apartment Building & 29 & 89 & 33 \\
\hline 11 & $\begin{array}{l}\text { Apartment Building at No. } 143 \text { Doc Ngu } \\
\text { street }\end{array}$ & 35.5 & 67 & 37 \\
\hline
\end{tabular}

(Source: Financial Department of Hoa Phat Group)

This indicates the needs for an effective information system and procedures for making pricing decisions to deliver the best economic performance for the enterprises and suit the real estate market conditions.

\section{Solutions for Improving the Information System and Procedures for Making Real Estate Pricing Decisions in Real Estate Enterprises}

For the purpose of improving the information system and procedures for making real estate pricing decisions in REEs, which help enterprises overcome the shortcomings in making pricing decisions for real estate, the author proposed as follows:

First: REEs should establish a team of experts to help managers make estimates for real estate business budgets and take responsibility for budgeting and directly helping managers make decisions on real estate business. This team can directly take personnel from related departments such as planning, organization, accounting, project management, construction teams, etc.

Second: The procedures for making pricing decisions should be as follows: 
Diagram: Procedures for making real estate pricing decisions in REEs

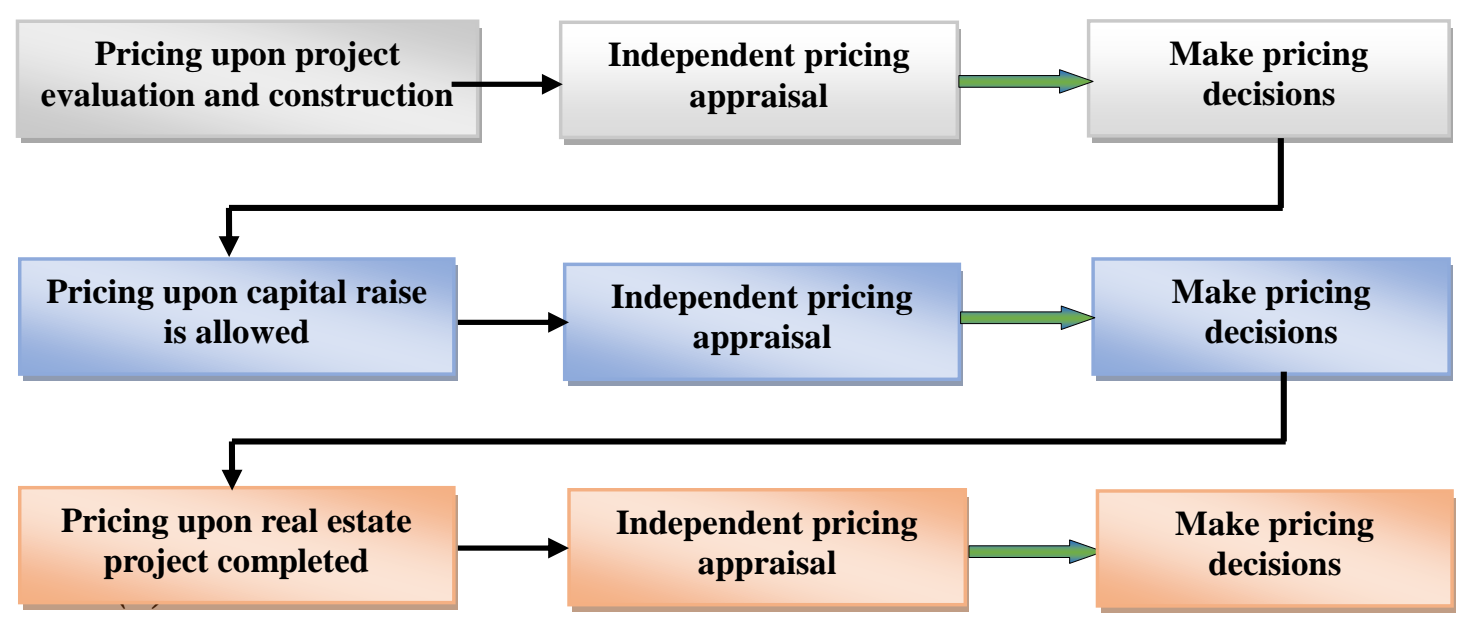

(1) Pricing decisions at the time of real estate project evaluation and construction

Surveys showed that most of the REEs have not really seen the important role of pricing decisions at this time of the project. It can be said that the pricing decisions in this period are usually made to make the project highly feasible to achieve the different objectives of the enterprise. If the real estate market is busy, where demands are higher than supply, then this does not affect REEs much. But when the downturn occurs, if the enterprises make inaccurate and unreasonable pricing decisions for real estate, it shall greatly affect the establishment of cost estimation system for project efficiency analysis, which results in the provision of wrong information to the making of management decisions. With the important role of pricing decisions for real estate in this period, the author would like to propose the steps for making real estate pricing decisions in this period as follows:

Step 1: Making pricing decisions for real estate by expert team

In this step, the expert team should use the cost method, the comparative method, and the income method for making pricing decisions. The established cost estimate reporting system for real estate projects shall be used as guiding information for the initial pricing decisions. In addition, the expert team should prepare additional analysis reports for making decisions such as:

+ The reports which analyze the socio-economic development strategies of the regions, localities and industries, the transport planning that affects the real estate sector and directly affects the real estate projects.

+ The reports which analyze housing market (adjoining buildings, villas), apartment buildings market. In these reports, the enterprise must show the estimated average price and the price successfully transacted on the market.

+ Reports on additional expenses incurred due to inflation of construction cost. This report should be made by enterprise based on the calculation of the average inflation coefficient over the last 3 to 5 years.

From there, the expert team shall have a scientific basis for making real estate pricing decisions and prepare reports on estimates of revenue, profit and loss and reports on the effectiveness of the project.

\section{Step 2: Independent appraisal firm}

Depending on the conditions of each enterprise, the independent appraisal of the price made by the expert team can be done by the enterprise on their own or by another independent appraisal firm. Then, based on the results of the independent appraisal, the expert team and the independent appraisal firm shall produce a report analyzing the pricing results, the increase and decrease and the causes for that and submit to the management board to make the final pricing decision.

\section{Step 3: Making pricing decisions}

In this step, the management board of the enterprise shall base on the pricing results analysis report of the two appraisal organizations to make the final pricing decision. This is the decision that shall influence the calculation of the project efficiency, product identification of the real estate project and customer group of the real estate project. 


\section{(2) Pricing decisions at the time when capital raise is allowed}

This can be considered as the most important pricing time of a real estate project, or in other words, a pricing decision at this time is one of the most important management decisions of the REEs. This pricing decision will directly response to the market acceptance of the project's products and will be almost critical to the success of the real estate project.

\section{Step 1: Making pricing decisions for real estate by expert team}

The basis for pricing decisions at this time is the pricing decisions made when the enterprise evaluated and developed the real estate project. However, due to the different times of making pricing decisions, the expert team should re-execute the analytical reports which have been made for the pricing process to obtain accurate information up to the present time. In addition, the price which was determined by the enterprise or an independent appraisal firm at the time of the project evaluation and development is the average price per square meter for real estate projects, such as the average prices per square meter for apartments, villas, and adjoining buildings. In fact, the cost prices per square meter of built real estate is the same, but due to the tastes for real estate of customers, due to the differences of real estate, such as the different directions of two apartments on the same floor, the customer's decisions to buy are affected. Therefore, in order to meet the market conditions and the needs of customers, in this period REEs need to make detailed pricing decisions for real estate of each apartment, villa or adjoining building on the basis of adjusting the average price.

Making detailed real estate pricing decisions for each property in the project is a complex task, which reflects the sensitivity of the pricing team with the real estate market, directly affecting the sales of the real estate enterprises. Enterprises can apply price adjustment method by coefficient. For example, the method of adjusting prices for apartments is as follows:

$>$ Identify factors that affect the real estate prices such as: location of the building, floor, apartment direction, usable area, private car park, etc.

$>$ Identify the adjustment coefficient for each affecting factor

In this step, the REEs have to choose the coefficients for the factors affecting real estate prices based on actual experience and business sensitivity. Normally, for each factor the most typical type is selected and coefficient of 1 is taken, the other types shall be adjusted by the coefficient in increasing or decreasing orders.

For example, in the real estate project there are 3 buildings, the building which has the best and most convenient location shall have the highest adjustment coefficient. The apartments on the best floors according to Asian concepts such as $8,9,10$, etc. shall have higher coefficients than the apartments on other floors. The enterprise can determine the coefficient of apartment position on each floor by criteria such as the number of openings (apartment in corner or at center), landscape in the balcony view, door direction to the East or the South or directions of stairs, garbage door, etc.)

$>$ Determining selling price for real estate.

Using the above results, REEs can determine the selling price for real estate by the formula:

\section{Real estate selling price $=$ Average real estate valuation price $*$ Apartment selling price coefficient}

The apartment selling price coefficient is the adjustment rate of the apartment unit price compared with the average unit price of the project. The apartment selling price coefficient is defined as the multiply of the adjusted coefficients.

\section{Step 2: Independent appraisal firm}

According to the author's recommendations, with the important role of pricing decisions in this period, after the pricing team has determined the real estate price, the enterprise should hire an independent appraisal firm to revalue the price determined by the expert team. The purpose of this step is to avoid the subjectivity of the enterprise itself and to give the enterprise the pricing decisions which ensure the market acceptance and achieve the profit goals of the enterprise.

\section{Step 3: Making pricing decisions}

In this step, like the same step at the time of project evaluation and construction, the enterprise management board shall base on the pricing results analysis report of the two appraisal organizations to make the final pricing decision. This is the decision that will affect the success of the real estate project.

\section{(3) Pricing decisions at the time when the project has been completed}

The pricing at the time when the project has been completed also includes three steps similar to the pricing at the two points of time above. However, the pricing at this time is based on the reporting system of performance results, 
fluctuations and causes of fluctuations for real estate business. In the surveyed REEs the real estate projects are normally divided into two cases.

Case 1: The real estate project has sold most of the properties since its launch. Then the pricing at the time of project completion shall not be paid attention by REEs. Normally in this case the REEs do not change or if so they often increase the selling price of the real estate.

Case 2: The real estate project still has many real estate products left. This case occurs when the enterprise make real estate pricing decisions which are inappropriate with the market. In this case, the enterprise's expert team should conduct a revaluation in full steps to revaluate the selling price to suit the actual cost as well as the market fluctuations and trends to meet the goals of the enterprise.

\section{Conclusions}

Based on the objectives, the paper has focused on solving the following issues:

\section{The paper has addressed the following key issues:}

Clarification and specify pricing decisions at three points of time during the project investment and construction process namely: the time of project evaluation and construction; the time when enterprises are allowed to raise investment capital from customers and the time when the real estate project has been completed. When pricing at different times, the business has different goals. Data and information systems to serve as the basis for pricing decision also different. Therefore, it is necessary to identify the time of pricing decision, that will help REEs make accurate and reasonable decisions.

Through the survey results, the paper has analyzed and evaluated the real situation of Vietnam's REEs in making pricing decisions for real estate. On that basis, solutions to complete the information system and pricing decisions for real estate making process for creating the highest economic efficiency for the REEs in the current market conditions would be proposed.

\section{Limitations of the paper}

On the basis of the results obtained in the paper, other researches could expand the sample size of the surveyed enterprises in the whole country.

\section{Implications for further research}

Research pricing model for real estate in REEs and what should be the effective pricing model for Vietnam's REEs.

\section{References}

Bodie Z., Merton R. (2000). Finance, Prentice Hall, 2000.

Colin Drury. (2005). Management Accounting for Business Decisions, Thomson Learning Publisher.

Do Minh Cuong. (2001). Văn hóa và triết lý kinh doanh (Business culture and philosophy), National Political Publishing House, Hanoi.

John B.Corgel, PH.D và Halbert C. David C.Ling, PH.D, Real Estate Perspectives - An introduction to real estate.

Luc Mach Hien. (2014). Định giá nhà ở thuoong mại xây dưng mới ở các doanh nghiệp đầu tu, xây dụng và kinh doanh

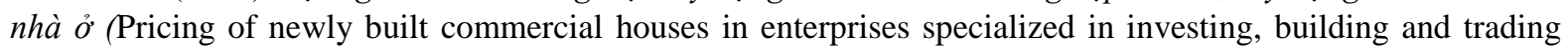
houses), PhD thesis, National Economics University.

Nguyen Dinh Do. (2004). Scientific research project at ministerial level "Hoàn thiện mô hình tổ chức kế toán quản trị và phân tích kinh doanh trong các doanh nghiệp sản xuất" (Improving the model of management accounting and business analysis in manufacturing enterprises), Academy of Finance.

Nguyen Thi Hong Nhung. (2012). Pháp luật về chuyển nhuợng quyền sử dụng đất trong kinh doanh bất động sản ở Việt Nam (Legislation on transfer of land use rights in the real estate business in Vietnam), PhD thesis, Hanoi Law University.

Ministry of Finance. (2014). Circular No. 158/2014/TT-BTC promulgating Vietnamese price appraisal standards No. 01, 02, 03 and 04, on October 27, 2014.

Severin Grabski et al. (2009). Management Accounting in Enterprise resource planning system, Elservier House, Jordan Hill.

Steven M.Bragg. (2009). Management Accounting Best practices, John Wiley \& Sons, Inc. 
Sterling, Conservatism. (1973). The fundamental principal of valuation, Financial Accounting Theory, McGraw-Hill.

The National Assembly of the Socialist Republic of Vietnam. (2013). Law No. 45/2013/QH13 of the National Assembly: Land Law, issued on November 29, 2013.

The National Assembly of the Socialist Republic of Vietnam. (2014). Law No. 66/2014/QH13 of the National Assembly: Real Estate Business Law, issued on November 25, 2014.

Trinh Dinh Dung. (2014). "Chiến lược phát triển thị trường bất động sản trong tiến trình hoàn thiện thể chế kinh tế thị trường định hướng xã hội chủ nghĩa" (Development strategy of the real estate market in the process of improving the socialist-oriented market economy institution), Tạp chí cộng sản (Communist Magazine), October 2014

Vu Anh. (2012). Pháp luật về kinh doanh bất động sản ở Việt Nam - nhũng vấn đề lý luận và thực tiê̂n (Legislation on real estate business in Vietnam - theoretical and practical issues), PhD thesis, Graduate Academy of Social Sciences.

Xiaosong Zheng. (2012). Management Accounting Practices in China: Current Key Problems and Solutions. Social Research, Nr. 4(29), 91-98. 